\title{
The Mindful Act of Translating Poetry from the Shoah. "with love and gratitude for much that was beautiful and unforgettable" 1 Selma Meerbaum-Eisinger
}

\author{
Courtney McDonald
}

In spite of all the atrocities committed in the time of the Shoah the human spirit survived. It survived in various ways, one way in particular was through poetry. Poetry encapsulates the human experience and alongside has the power to give a voice to those who cannot speak. ${ }^{2}$ This power is particularly important with regard to the victims of the Shoah. One such victim was the Czernowitz poet Selma Meerbaum-Eisinger, who perished at the age of eighteen in the Michailovca labour camp. ${ }^{3}$ A collection of her poetry has survived, and with that her voice and experiences survived. Translating such poetry allows the voices to be heard today. This role for a translator comes with certain responsibilities. Firstly, the translator must understand the role language had for both destruction and survival during in the context of the Shoah. In addition, the specific role poetry has for cultural survival and the specific challenges poetry poses in relation to translations. Once the translator gained an appreciation for the poet's context and language, then a translator can produce an accurate and engaging translation for the reader. This essay will explore these responsibilities and touch on my own attempt at mindfully translating two poems by Meerbaum-Eisinger.

The misuse of language was crucial in the success of the deception in all sectors of the Nazi Regime. ${ }^{4}$ The public was misled by language, as the head of SS, Heinrich Himmler, named camps such as Dachau "Schutzlager" (Protective Camps), giving the false premise that the camp would indeed protect prisoners from hostile crowds. ${ }^{5}$ However in reality, the camp was full of abuse, torture, and murder. ${ }^{6}$ The victims were also subjected to cruelly twisted words. When entering the camps the victims were faced with facades of language as the gates had slogans like "Arbeit macht frei" (Work sets you free) and "Jedem das Seine" (To each his own/To each what he deserves). This hollowed and sadistic weaponization of language added

\footnotetext{
${ }^{1}$ Jacon Sontag Four Poems pp.13

2 Jean Boase-Beier et al The Palgrave Handbook of Literary Translation pp. 25

${ }^{3}$ Anna-Dorothea Ludewig, „Ein Vorhof zum Paradies “: Das Czernowitz-Bild in der deutsch-jüdischen Literatur pp. 222

${ }^{4}$ Jean Boase-Beier Translating the poetry of the Holocaust: translation, style and the reader pp.68

${ }^{5}$ Mordecai Schreiber Explaining the Holocaust: How and Why It Happened pp.76

${ }^{6}$ Ibid pp. 76
} 


\section{(6) NEKE Thenenezeatand burmal of Translation Studies}

to the demoralisation of the camps. These deathcamps were designed to destroy any hope and leave the victims wishing for death. ${ }^{7}$

Silence is also deadly. In Hannah Arendt's book Eichmann in Jerusalem: A Report on the Banality of Evil, she scrutinizes how "terrifyingly normal" people perpetuated the Nazi terror due to their lack of critical thinking and their wilful silence. Where silence thrived, so did the atrocities. In stark contrast, sound and critical thinking is at the forefront of poetry. The victims created agency in their poetry ${ }^{8}$, and thus language became an instrument of survival for them and their experiences In doing so, they gave the world aesthetic artefacts. ${ }^{9}$ Due to the possible artistic and alluded nature of poetry, it cannot be viewed as historical documentation. ${ }^{10}$ Rather, the poetry shows how the artistic spirit of humans confronts and interprets life. Through poetry, we gain another perception on life. The poetry from the Shoah confronts many painful states of mind such as sadness, guilt, grief, and horror. ${ }^{11}$ Through these aesthetic artefacts the message can be passed on to all readers of how the human spirit can be brutalised and how it can persevere. Whether the poetry was written during or in the aftermath of the Shoah, the true importance of this poetry is that the victims always had a voice and deserved and will always deserve to be heard. Today translation can deliver these valuable voices and messages to another audience.

Many English readers are still interested in the Shoah due to its significance in modern history $^{12}$, and as such there are wide-ranging resources in English on the Shoah. Translated poetry is for English reader wishing to gain an enhanced understanding and remembrance. ${ }^{13}$ It is an enhancement from historical facts into tangible feelings, as the power of poetry is that the reader feels what the poet feels. ${ }^{14}$ The traumatic nature of the poetry may make it difficult for readers to access the poetry. This, however, should not stop the production of translations. Rather, the modern role of translating trauma is one of accountability. ${ }^{15}$ While we cannot reverse or change the past, today we can assist in understanding and remembrance.

\footnotetext{
${ }^{7}$ Mordecai Schreiber Explaining the Holocaust: How and Why It Happened pp. 77

${ }^{8}$ Alex Pillen Language, Translation, Trauma pp.105

9 Henry W. Pickford The Sense of Semblance: Philosophical Anlayses of Holocaust Art pp.18

${ }^{10}$ Jean Boase-Beier Translating the poetry of the Holocaust: translation, style and the reader pp. 124

${ }^{11}$ Ibid pp. 123

12 Ibid pp. 123

${ }^{13}$ Jean Boase-Beier Translating the poetry of the Holocaust: translation, style and the reader pp.151

${ }^{14}$ Barbara Folkart Second Finding: A Poetics of Translation pp.427

15 Jean Boase-Beier Translating the poetry of the Holocaust: translation, style and the reader pp.150
} 


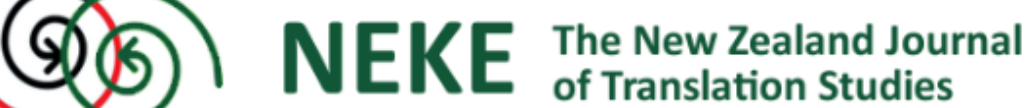

Translation has the potential to engage future and more widespread readers ${ }^{16}$ and with this engagement comes along the responsibility of trust. ${ }^{17}$ As the translator is the mediator between the two cultures and languages, the translation must be reliable, especially when translating this delicate literature. So, a translator works as a scholar ${ }^{18}$ looking into the intricacies of language in both poetry and translation.

Poetry is an interplay of social and cultural use of language ${ }^{19}$ and a poet's force is how they connect the two in their own style. The subtle and personal aspect of style ${ }^{20}$ is tricky to firstly discern, and then to effectively translate. Even more so with poets, as they are known to forge their own idiosyncratic signifiers by drawing on the potential of language. ${ }^{21}$ This means a translator needs be aware of the "markedness" of an utterance in the SL and the relevance of this markedness with regard to the poet's style and message. ${ }^{22}$ This cognitive aspect of poetry must be observed by the translator. In order to achieve the cognitive force of the original a translator should continually "doubt, argue, discredit, contradict, disbelieve, counter, question, vacillate, and even act hypocritically" ${ }^{23}$ their understanding on how both SL and TL work. As poetry transcends the narrow meaning of language, so should the translation. ${ }^{24}$ Translating poetry can be therefore both strengthening and destabilising for the TL's canon. ${ }^{25}$ Any utterance in any language can have several meanings. ${ }^{26}$ The meaning of the utterance may not be in the words themselves, they may be dependent on the context, and thus interpretation is needed. ${ }^{27}$ This is the same for translation. A translator works to comprehend the sense of the source text (ST) and produce it in consideration of the TL recipient. ${ }^{28}$ Rather than a comparison of two language, translation is more aligned to the interpretation of two text in two different languages. ${ }^{29}$ The interpretation focuses more on than substantive content

\footnotetext{
${ }^{16}$ Ibid pp. 144

${ }^{17}$ Jean Boase-Beier Translating the poetry of the Holocaust: translation, style and the reader pp. 58

${ }^{18}$ Laurence K. P. Wong \& Chan Sin-wai The Dancer and the Dance: Essays in Translation Studies pp. 1

${ }^{19}$ Ibid pp. 81

${ }^{20}$ Ibid pp. 170

${ }^{21}$ Barbara Folkart Second Finding: A Poetics of Translation pp. 429

${ }^{22}$ Laurence K. P. Wong \& Chan Sin-wai The Dancer and the Dance: Essays in Translation Studies pp.81

${ }^{23}$ Douglas Robinson, Becoming A Translator: An Introduction to the Theory and Practice of Translation pp.90

${ }^{24}$ Rainer Guldin Translation as Metaphor pp. 115

${ }^{25}$ Ibid pp.93

${ }^{26}$ David Bellos Is That a Fish in Your Ear? Translation and the Meaning of Everything pp.1

${ }^{27}$ Ibid pp. 24

${ }^{28}$ Marta Chroma Making sense in legal translation pp.133

${ }^{29}$ Ibid pp. 133
} 


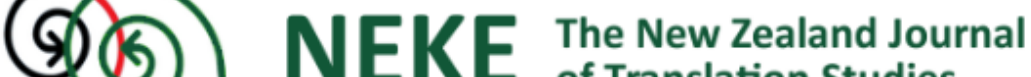 of Translation Studies}

of the text, rather than creating identicality. ${ }^{30}$ This meaning that the message has greater significance than the form and/or visibility of the ST. This notion of translation is the preference for acceptability over adequacy. To translate adequately means to observe to the source culture norms, in comparison to translate acceptably is to observe the target culture norms. ${ }^{31}$ It is the translator's responsibility to decide what norms should have more priority over others. Poetry places importance on both the message and the form, and so a translator must interpret how best to preserve the poet's force in the SL and translate that as precisely in the TL. ${ }^{32}$

A beautiful feature of poetry is its musicality, and this beautiful feature poses a challenge for a translator. Poets utilise prosody to emphasize and to create a tone, and this is demanding to translate ${ }^{33}$ due to the different perception and production of sounds each language has. Rhyme also poses challenges for a translator. When a poem has rhyme, it is generally intentional and therefore is an important feature. However, due to the differing lexicons languages have, a rhyme cannot be easily substituted with the exact lexical equivalent. In order to retain an equivalent sense of the rhyme, interpretation of poem is usually required for the translation to have the same rhyme scheme. This means that the translation will have to deviate from the original on both word and syntactic levels. The changes may be seen as a reduction of authenticity to the words and the exact message, though when the rhyme is not included in the translation then it is loss of authenticity to the poem's sense. It is the translator's responsibility to decide what is best to represent the poet and engage the reader. ${ }^{34}$

A well-informed translation may not be engaging. If a translation is too abstract, a reader may become disinterested quickly. If a translation is too simplified, a reader may come away with a compromised understanding. A translator must work in consideration with reader's competency and potential. ${ }^{35}$ This is for both the language and literature. An English speaker will recognise loanwords like kindergarten, strudel, zeitgeist come from German. A speaker interested in modern history will also recognise places like Auschwitz and Dachau, and their role in the Shoah. Keeping these kinds of words in the English translation gives a clear link to

\footnotetext{
${ }^{30}$ Ibid pp. 133

${ }^{31}$ Jean Boase-Beier et al The Palgrave Handbook of Literary Translation pp.474

${ }^{32}$ David Bellos Is That a Fish in Your Ear? Translation and the Meaning of Everything pp.24

${ }^{33}$ Laurence K. P. Wong \& Chan Sin-wai The Dancer and the Dance: Essays in Translation Studies pp.10

${ }^{34}$ Jean Boase-Beier et al The Palgrave Handbook of Literary Translation pp. 32

${ }^{35}$ Jean Boase-Beier Translating the poetry of the Holocaust: translation, style and the reader pp.71
} 


 of Translation Studies}

the German original, and in doing so it makes the reader feel transported into another culture. While keeping a word that is not well integrated into the TL repertoire, like Konzentrationslager (concentration camp) or Herrenrasse (master race), disrupts fluency and can lead to disengagement. Poetry is cognitively challenging, yet at the same time poetry enables us to identify with each other. A translator needs to find the right balance of expectation and extension to render the poet's voice and message fittingly.

The voice of Selma Meerbaum-Eisinger is deserving of a mindful translation. One reason is how her poetry embodies a Jewish culture and spirit once present in her home city of Czernowitz. Czernowitz was a multi-ethnic city deeply influenced by Jewish culture. An Austrian census conducted in 1910, as Bukovina was still under the rule of the Habsburg Empire, recorded 102,925 Jewish citizens in the population close to 800,000 inhabitants. ${ }^{36}$ Most of the Jewish inhabitants spoke German as their mother tongue, while those in the countryside spoke Yiddish. Ukrainian and Romanian were also part of many people's language repertoire. ${ }^{37}$ With an abundance of cultures and education, Czernowitz was thought of as a liberal city in the East, as the poet Rosa Ausländer described it, "Das viersprachige Czernowitz war eine musische Stadt, die viele Künstler, Dichter, Kunst-, Literatur- und Philosophieliebhaber beherbergte. "38 (The quadrilingual Czernowitz was an artistic city that hosted many artists, poets, lovers of art, literature, and philosophy.)

After World War One, Czernowitz was seized by the Kingdom of Romania and with that came a repressive regime towards the Jewish community, including anti-Semitic laws which banned the Jewish Press. ${ }^{39}$ More suffering was soon to follow, as this epicentre of Eastern Jewish culture was a target for the Nazi. In spite of the persecution, there was a second blossoming of a literary phenomenon in Czernowitz. ${ }^{40}$ This literary phenomenon is attributed to poets from assimilated Jewish family, whose mother tongue was German. ${ }^{41}$ They were writing lyrical poetry in modern and impressionistic approaches ${ }^{42}$ and in doing so defied their

\footnotetext{
${ }^{36}$ Anna-Dorothea Ludewig, „Ein Vorhof zum Paradies “: Das Czernowitz-Bild in der deutsch-jüdischen Literatur pp. 219

${ }^{37}$ Ibid pp. 219

${ }^{38}$ Ibid pp. 220

${ }^{39}$ Ibid pp. 217

${ }^{40}$ Petro Rychlo "Sprache, du heilige”: Sprachreflexionen in der deutschen Dichtung der Bukowina pp.30

${ }^{41}$ Ibid pp. 30

42 Petro Rychlo "Sprache, du heilige": Sprachreflexionen in der deutschen Dichtung der Bukowina pp.30
} 


 of Translation Studies}

restrictive circumstances. These poets are a part of the Shoah Generation ${ }^{43}$ and include the likes of Manfred Winkler, Alfred Margul-Sperber, David Goldfeld, as well as cousins Paul Celan and Selma Meerbaum-Eisinger. ${ }^{44}$ As a result of the persecution, Czernowitz became known as a "sunken city" 45 as it was stripped of its Jewish soul. Poetry from the Shoah generation provides the world with artefact of voices from forcibly erased heritage.

The pervasive force of the persecution was never far from the poets' thought. However, one historical event does not define a person or a poet, the entirety of life does. It is important to recognise that a poet like Meerbaum-Eisinger was not just a victim of the Shoah ${ }^{46}$, she was also just like every other teenage girl deciphering her feelings of love, desire, and trepidation. ${ }^{47}$ This embodiment of a youthful spirit makes her work timeless, as each generation is able to identify with the mixture of light and melancholic mood in Meerbaum-Eisinger's poetry.

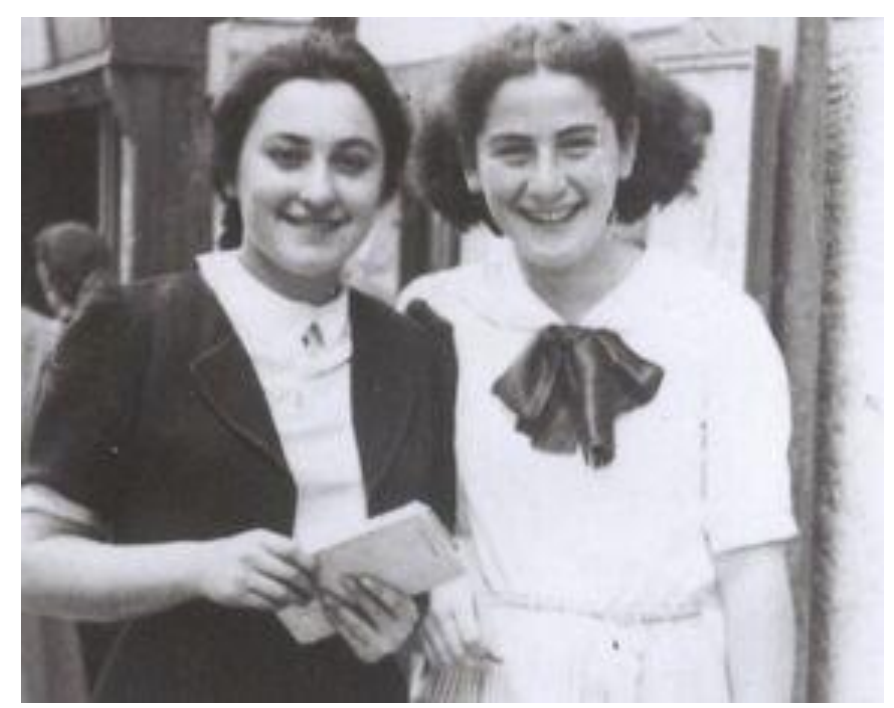

Selma Meerbaum-Eisinger (right) with her friend Else Keren in Czernowitz

Source: https://www.weser-kurier.de/startseite_artikel,-IhreGedichte-sind-vor-allem-als-Lieder-bekannt-_arid,1187314.html

I chose the two poems to show the insightful cultural and personal aesthetic artefacts in Meerbaum-Eisinger's collection from Ich bin in Sehnsucht eingehüllt (I am engulfed in longing). Lied (Song) dated 25/12/1939 is impressionist depiction of the deportations to ghettos forced upon Jews in Czernowitz. While Welke Blätter (Wilted Leaves) is dated slightly earlier at 24/09/1939 and does not explicitly mention the persecution, it is a snippet of the great turmoil and premonition felt by Meerbaum-Eisinger.

\footnotetext{
${ }^{43}$ Anna-Dorothea Ludewig, „Ein Vorhof zum Paradies “: Das Czernowitz-Bild in der deutsch-jüdischen Literatur pp. 223

${ }^{44}$ Evander Lomke Harvest of Blossoms: Poems from a Life Cut Short pp.208

${ }^{45}$ Anna-Dorothea Ludewig, „Ein Vorhof zum Paradies “: Das Czernowitz-Bild in der deutsch-jüdischen Literatur pp. 223

${ }^{46} \mathrm{~J}$ Jean Boase-Beier Translating the poetry of the Holocaust: translation, style and the reader pp.98

${ }^{47}$ Evander Lomke Harvest of Blossoms: Poems from a Life Cut Short pp.209
} 


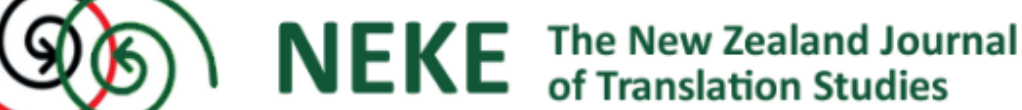

\section{Lied}

Heute tastest du mir weh.

Song

Rings um uns war Schweigen nur,

Today you hurt me.

Schweigen nur und Schnee.

All around us silence lies,

Himmel, war nicht wie Azur,

silence and snow only.

blau jedoch und voll mit Sternen.

Though not azure, the sky

Windeslied erklang aus fernsten Fernen.

was blue and full of stars.

The song of wind rung out from far afar.

Heute warst du mir ein Schmerz.

Häuser waren da, so weiß verschneit,

Today you were a pain for me.

alle in des Winters Kleid.

Houses there were snow white,

Ein Akkord in tiefer Terz

all dressed in Winter's bite.

was in unsrer Schritte Klang.

A minor third in $\mathrm{D}$

Bahnsirenen heulten lang...

is how our steps sound.

Long the train sirens hound...

Heute war es wunderschön.

Schön wie tiefverschneite Höh’n,

Today was so beautiful.

eingetaucht im Abendglutenring.

Beautiful as snow-covered hills,

drenched in the evening's glowing ring.

Heute tatest du mir weh.

Heute sagtest du mir: geh!

Today you hurt me.

Und ich - ging.

Today you told me - leave!

And I - left. 


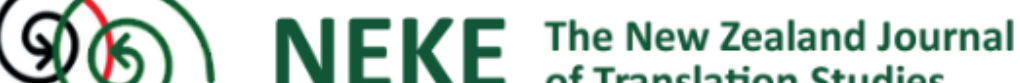 of Translation Studies}

\section{Welke Blätter}

Plötzlich hallt mein Schritt nicht mehr,

sondern rauschet leise, leise,

wie die tränenvolle Weise,

die ich sing', von Sehnsucht schwer.

Unter meinen müden Beinen,

die ich hebe wie im Traum,

liegen tot und voll von Weinen

Blätter von dem großen Baum.

\section{Wilted Leaves}

Suddenly my step stops echoing,

rather rustles quietly, quietly

like the tearful melody,

I sing heavy with longing.

Under my tired legs,

which I lift like in a dream,

lie dead and full of tears

leaves from the great evergreen. 


\section{(D) NEKE The Newrealand Juounal of Translation Studies}

As identicality cannot be achieved in translation, I decided that my translations should be interpretations. By researching and reading around Meerbaum-Eisinger's life and poetry, I was able to make informed interpretations that exemplify her voice for the English reader. Each poem has one specific instance where I have interpreted.

The influence of music shines in Meerbaum-Eisinger's poetry. She grew up surrounded by music, as her mother brought, sold, and mended pianos for a living. ${ }^{48}$ She masterfully utilised prosody and rhyme to create melodies and was so successful that posthumously a few of her poems have been set to music. It was therefore critical to retain this feature, and so I prioritised keeping the rhyme scheme over the individual words. While in some lines the words only needed to be rearranged like in Lied with "silence and snow only", some words needed to be added or subtracted. This was the case in the second stanza of Lied. This stanza has the rhyme scheme of ABBACC. If I had literally translated the first line "Heute warst du mir ein Schmerz" as "Today you were to me a pain", it would have come across stilted, and so I decided it would be better to interpret the fourth line. I translated "Ein Akkord in tiefer Terz" as "A minor third in D" because D minor is the scale used for melancholic music like in Mozart's Requiem and Joseph Haydn's Lamentatione. This interpretation is a more exact tone more than the original, however it retains the rhyme and the musical prowess of MeerbaumEisinger.

Czernowitz's lush nature often appears in Meerbaum-Eisinger's poems, in particular the region's greenery. In Welke Blätter, Meerbaum-Eisinger uses the hypernym "Baum” (tree) for the final word, while my translation deviates as it has the hyponym "evergreen". The evergreen Tannen (fir trees) appear in many of Meerbaum-Eisinger's poems, for example in Kristall (Crystal) where she writes, "Die Tannen stehen frisch und grün"(The fir trees are standing fresh and green) and in Nachmittag (Afternoon), "Alle Tannen sind ganz neu ergrünt" (All the fir trees are newly green). It is therefore appropriate to use the hypernym, as it does not deviate from the poet's repertoire and the rhyming scheme of the second half of the poem, $\mathrm{ABAB}$, is preserved as both dream and evergreen end in nasal constant. By mindfully interpreting Meerbaum-Eisinger's words and expanding on then, I have captured her rhyme, fluidity, and feeling for the English reader.

\footnotetext{
${ }^{48}$ Julia Negra \& Ildiko Molnar Selma Meerbaum-Eisinger with her Grandmother
} 


 of Translation Studies}

There is much more to explore in Meerbaum-Eisinger's poetry, as there is much more to explore in translation. To begin to explore a translator must have a foundational understanding of their task. A translator is the mediator for both people and languages. Languages and people have both limitations and expectations, and a translator works to understand and perform them. People and their language are greatly influenced by their contexts and so a translator needs to be aware of the significance of that in the text. This of particular importance when translating sensitive texts like the poetry from the Shoah. In spite of the vast and immense efforts to dehumanise and silence voices like Meerbaum-Eisinger's, the poetry from the Shoah show how language is crucial as an instrument of survival. To ensure that the voices live on, a translator should approach this poetry in a scholarly way by continually seeking reasons for their interpretations and so to understand their consequences. The act of mindful translation enables all that was beautiful and unforgettable to be pass on to another readership, so that they too can appreciate the touching voices of those who have and will always be deserving to be heard.

\section{Bibliography}

David Bellos, Is That a Fish in Your Ear? Translation and the Meaning of Everything (New York: Faber \& Faber 2011) pp. 1-81

Jean Boase-Beier, Translating the poetry of the Holocaust: translation, style and the reader (London/New York: Bloomsbury 2015) pp. 58-151

Jean Boase-Beier, Lina Fisher \& Hiroko Furukawa, The Palgrave Handbook of Literary Translation (London: Palgrave Macmillan 2018) pp.25-474

Marta Chromá, "Making sense in legal translation” Semiotica, (August 2014) pp.133

Barbara Folkart, Second Finding: A Poetics of Translation (Ottawa: University of Ottawa Press 2007) pp. 427-429

Rainer Guldin, Translation as Metaphor (London/New York: Routledge 2016) pp.93-115

Evander Lomke, "Harvest of Blossoms: Poems from a Life Cut Short" Confrontation 102/103 (Winter 2008) pp. 208-209 


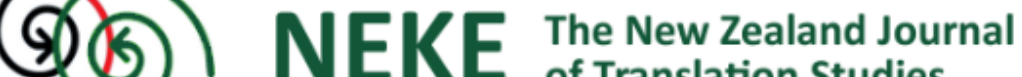 of Translation Studies}

Anna-Dorothea Ludewig, „Ein Vorhof zum Paradies“: Das Czernowitz-Bild in der deutschjüdischen Literatur" Zeitschrift für Relgions- und Geistesgeschichte 58/3 (January 2006) pp. 217-223

Julia Negra \& Ildiko Molnar, Selma Meerbaum-Eisinger with her Grandmother (Targu Mures, Romania 2003) https://www.centropa.org/photo/selma-meerbaum-eisinger-hergrandmother

Henry W. Pickford, The Sense of Semblance: Philosophical Analyses of Holocaust Art (New York: Fordham University Press 2013) pp. 18

Alex Pillen, „Language, Translation, Trauma” Annual Review of Anthropology (2016) pp.105

Douglas Robinson, Becoming A Translator: An Introduction to the Theory and Practice of Translation (London/New York: Routledge 2007) pp. 90

Petro Rychlo, "Sprache, du heilige": Sprachreflexionen in der deutschen Dichtung der Bukowina" Pytannia literaturoznavstva 96 (December 2017) pp.30

Mordecai Schreiber, Explaining the Holocaust: How and Why It Happened (Cambridge: Lutterworth Press 2015) pp.76-78

Jacob Sonntag, "Four Poems" Jewish Quarterly (May 2013) pp.13

Laurence K.P Wong \& Chan Sin-Wai, The Dancer and the Dance: Essays in Translation Studies (Newcastle upon Tyne: Cambridge Scholars Publishing 2013) pp. 1-170 